\title{
KONTRIBUSI HUTAN RAKYAT TERHADAP KETAHANAN PANGAN RUMAH TANGGA PETANI KECAMATAN RUMPIN, KABUPATEN BOGOR
}

\author{
The Contribution of Private Forest to Household Food Security in Subdistrict Rumpin, \\ District Bogor
}

\author{
Siti Nur Indah Lestari ${ }^{*}$, Hardjanto ${ }^{2}$, dan Yulius Hero ${ }^{2}$
}

(Diterima Juni 2018/Disetujui Agustus 2018)

\begin{abstract}
Private forest is one of the alternatives to support food security and household income. The research is located in village of Cidokom, Leuwibatu, and Mekarjaya, Subdistrict of Rumpin with 66 respondents. This study aims to analysis contribution of private forest to the total household income and food security of farmer households Data was collected by field observation, interview and literature study. Analysis of contribution to food security was done by calculating total energy from all crop production with unit of cap/cal/day by comparing the recommended daily consumption of energy and nutritional value (AKG) of $2150 \mathrm{kcal} / \mathrm{person} / \mathrm{day}$. The level of household food security is measured by using food share. Food share is crossclassification of two indicators of food security. The two indicators are the share of food expenditure and the adequacy of energy consumption ( $k c a l)$. The results showed that (1) The average contribution of private forest for household income from timber plantation is $10.63 \%$ and food crops is $30.22 \%$ of total income, (2) there are 46 types of crops which contribute to food security per day with average $393.70 \mathrm{cal} / \mathrm{cap} /$ day or $18.75 \%$ from total energy/day/person,(3) the distribution of households that have food resistant (TKE>90\%) is $69,69 \%$.
\end{abstract}

Key Words: Private forest, agroforestry, food security

\section{PENDAHULUAN}

Hutan rakyat memberikan kontribusi terhadap ketahanan pangan serta mendukung kehidupan yang berkelanjutan (Widiarti 2004). Pertumbuhan penduduk yang semakin meningkat, tingginya persentase rumah tangga miskin, serta keterbatasan lahan pertanian untuk memenuhi kebutuhan pangan menyebabkan kebutuhan lahan untuk budi daya tanaman pangan semakin besar. Optimalisasi pemanfaatan sumberdaya hutan rakyat sebagai penyedia pangan merupakan salah satu wujud peran hutan rakyat terhadap ketersediaan pangan secara langsung (Dephut 2009).

Ketahanan pangan berdasarkan hasil konferensi internasional World Food Summit 1996 didefinisikan sebagai kondisi ketika semua orang, setiap saat, memiliki akses fisik dan ekonomi terhadap pangan yang aman dan bergizi cukup untuk memenuhi kebutuhan pangan dan preferensi makanan untuk hidup aktif dan sehat ( FAO 2006). Sedangkan menurut UU Nomor 18

\footnotetext{
1 Mahasiswa Pascasarjana PS Ilmu Pengelolaan Hutan,

Fakultas Pascasarjana, IPB

* Penulis korespondensi:

e-mail: indahtegal@gmail.com

2 Staf Pengajar Dept. Manajemen Hutan, Fakultas

Kehutanan IPB
}

Tahun 2012 tentang pangan, ketahanan pangan adalah kondisi terpenuhinya pangan bagi negara sampai dengan perseorangan, yang tercermin dari tersedianya pangan yang cukup, baik jumlah maupun mutunya, aman, beragam, bergizi, merata, dan terjangkau serta tidak bertentangan dengan agama, keyakinan, dan budaya masyarakat, untuk dapat hidup sehat, aktif, dan produktif secara berkelanjutan.

Kontribusi pangan dari kawasan hutan diperoleh melalui program PHBM dengan sistem tumpangsari. Di Provinsi Jawa Barat dengan program pengembangan padi gogo dengan pola PHBM menghasilkan rata-rata 3.1 ton hingga 4.6 ton per ha/musim (Dwiprabowo et al.2011), serta di Kabupaten Sukabumi, KPH Sukabumi sejak tahun 2005 hingga 2009 melalui praktek pengelolaan hutan dengan sistem tumpangsari, yaitu dengan tanaman Padi, Jagung, Ubi Kayu dan KacangKacangan memberikan kontribusi mencapai senilai Rp 83.21 Milyar (Bangsawan dan Dwiprabowo 2012). Terdapat sekitar 26 jenis tanaman pangan prioritas yang dihasilkan dari hutan di Indonesia (Suhardi et al. 1999).

Hutan rakyat berkembang dari kebijakan pemerintah menanam tanaman berkayu pada lahan kosong dan tidak produktif, yaitu pada program rehabilitasi hutan di dalam kawasan dan lahan di luar kawasan hutan. Program rehabilitasi lahan tahun 2009 s/d 2012 seluas 2 073773 ha (Kemenhut 2013). Penambahan luas dan 
pengembangan hutan rakyat terus meningkat dari tahun ke tahun. Salah satu faktor pendukung tingginya minat masyarakat mengembangkan hutan rakyat adalah jaminan dan kepastian atas pemanfaatan hasil hutan serta pemilik lahan memiliki kebebasan untuk menentukan jenis dan pola tanam sesuai kebutuhannya.

Hutan rakyat memiliki potensi sebagai penghasil pangan dan meningkatkan kesejahteraan masyarakat. Hutan rakyat mempunyai manfaat ekonomi, ekologi dan sosial (Hardjanto 2003). Meningkatnya pasar dan harga kayu diharapkan meningkatkan penghasilan petani hutan rakyat yang juga akan meningkatkan perekonomian wilayah. Pengelolaan hutan rakyat dapat dikembangkan untuk mendukung ketahanan pangan rumah tangga petani. Hutan rakyat berkontribusi pada ketersediaan pangan dan peningkatan akses pangan melalui pendapatan yang diperoleh dari pengusahaan hutan rakyat. Terdapat tiga pola pengembangan tanaman hutan rakyat, yaitu: murni (monokultur), campuran dan agroforestri (Darusman et al. 2014). Pola tanam campuran terutama agroforestri merupakan sistem yang cukup baik dikembangkan untuk hutan rakyat dalam mendukung ketahanan pangan (Hardjanto 2003).

Pola agroforestri paling diminati oleh masyarakat, karena mampu menghasilkan panen harian, mingguan, bulanan dan tahunan/jangka panjang (De Foresta et al. 2000). Pola agroforestri merupakan pola optimalisasi lahan yang mengkombinasikan produksi tanaman pertanian dan tanaman hutan dan/atau hewan, secara bersamaan atau berurutan pada unit lahan yang sama dapat meningkatkan hasil lahan secara keseluruhan (Darusman et al. 2014).

Pengelolaan hutan rakyat dengan sistem agroforestri atau tumpangsari dapat berkontribusi pada ketersediaan pangan (Mbow et al. 2014). Komoditas tanaman pangan yang dapat dikembangkan di hutan rakyat dikelompokkan dalam beberapa jenis komoditas seperti biji-bijian (jagung, kacang, kedelai, kacang tanah dsb), buah (nanas, jeruk, pepaya, rambutan, dan sebagainya), Umbi-umbian (ketela pohon, ubi, garut, ganyong, dan sebagainya), tanaman obat (Jahe, Kunyit, Kunir, Kapulaga, dan sebagainya) (Aju 2014; De Foresta 2000; Pimentel et al. 1997).

Kecamatan rumpin memiliki luas hutan rakyat yang tertinggi di Kabupaten Bogor yaitu 2218,60 ha pada tahun 2011 (Distanhut 2011). Petani hutan rakyat di Kecamatan Rumpin rata-rata menanam tanaman keras yaitu kayu Sengon (Falcataria moluccana Miq) dan kayu Afrika ( Maesopsis eminii Engl), dan juga juga menanam tanaman pangan seperti jagung, singkong serta tanaman buah-buahan seperti durian, duku, kecapi, manggis, mangga, dan cempedak, selain itu juga menanam tanaman semusim seperti jahe, lengkuas dan kapulaga (Mudhofir 2015). Di sisi lain Kabupaten Bogor merupakan kabupaten di Provinsi Jawa Barat dengan jumlah penduduk miskin terbanyak, yaitu sekitar 446 040 orang atau sekitar 9.20\% (BPS 2016). Kondisi kepadatan penduduk yang cukup tinggi dan jumlah penduduk miskin yang tinggi memberikan pengaruh negatif terhadap ketahanan pangan, lingkungan dan indeks pembangunan manusia di Kabupaten Bogor (Pemkab Bogor 2014).

Pengembangan hutan rakyat dilakukan dengan menanam pohon dan tanaman pangan, sehingga hasilnya diperoleh sebagai salah satu sumber pangan dan pendapatan. Darusman dan Hardjanto (2006) berpendapat bahwa kontribusi pendapatan hutan rakyat berkisar tidak lebih dari $10 \%$ dari pendapatan total petani dan dianggap sebagai pendapatan sampingan serta bersifat insidentil. Pendapatan yang diperoleh dari pengusahaan hutan rakyat digunakan untuk meningkatkan akses pangan. Keterjaminan akses pangan pada tingkat rumah tangga hasus dicapai, sehingga kebutuhan pangan untuk setiap anggota rumah tangga dapat terpenuhi setiap saat (Syarief 1992). Terbatasnya akses pangan rumah tangga terhadap pangan menyebabkan harga pangan menjadi relatif lebih mahal. Hutan rakyat campuran di Kabupaten Sukabumi, Jawa Barat berkontribusi pada pendapatan rumah tangga sebesar Rp 6.93 juta pertahun (60.6\%), dengan pendapatan dari jenis tanaman kayu sebesar Rp 1.29 juta pertahun (16.3\%) (Rachman 2009).

Akses pangan rumah tangga dipengaruhi oleh pendapatan baik dari pertanian maupun non pertanian. Akses pangan tergantung pada kemampuan kontrol pangan yang dipengaruhi oleh daya beli atau pendapatan masyarakat (Maxwell dan Frankenberger1992). Indikator yang digunakan dalam akses pangan adalah total pendapatan, pendapatan dari tanaman dan ternak, upah, harga jual, pasar, akses jalan, dan kiriman uang (Chung et al. 1997). Rendahnya akses pangan disebabkan pendapatan yang rendah dapat menyebabkan ketidaktahanan pangan rumah tangga (Suhardjo 1996).

Pengelolaan tanaman musiman pada lahan agroforestri dapat dikatakan belum cukup intensif dibandingkan dengan pola tanam kayu. Hal ini dapat dilihat dari banyaknya petani hutan rakyat yang tidak memiliki pola penataan khusus pada tanaman musiman dan tanaman pangan lain yang ditanam. Sebagian besar petani masih memanfaatkan tanaman musiman secara subsisten, meskipun terdapat beberapa petani yang memanfaatkan tanaman musiman secara komersil dalam jumlah yang cukup besar (Hardjanto 2003). Hasil studi literature menunjukkan bahwa kajian hutan rakyat di Kabupaten Bogor terutama Kecamatan Rumpin yang telah dilakukan yaitu berupa potensi dan kontribusi hutan rakyat terhadap pendapatan rumah tangga (Mudhofir 2015). Penelitian bertujuan untuk (1) Menganalisis kontribusi pendapatan dari hutan rakyat terhadap total pendapatan rumah tangga petani dan (2) Menganalisis kontribusi hutan rakyat terhadap ketahanan pangan rumah tangga petani di Kecamatan Rumpin, Kabupaten Bogor. 


\section{METODE PENELITIAN}

\section{Waktu dan Lokasi Penelitian}

Penelitian ini dilaksanakan Bulan Maret sampai dengan Juni 2016 di Kecamatan Rumpin Kabupaten Bogor. Pemilihan lokasi penelitian dilakukan secara purposive yaitu penentuan tempat tersebut secara sengaja dengan pertimbangan adanya praktek pengelolaan hutan rakyat yang cukup potensial oleh masyarakat sebagai salah satu sumber pangan dan pendapatan. Di samping itu, Kecamatan Rumpin merupakan kecamatan yang memiliki hutan rakyat paling luas di Kabupaten Bogor yaitu 2218.60 ha (Distanhut 2011).

\section{Pengumpulan Data}

Desa yang dijadikan sebagai sampel penelitian adalah tiga desa yaitu Desa Cidokom, Desa Leuwibatu, dan Desa Mekar Jaya dengan jumlah keseluruhan responden sebanyak 66 rumah tangga petani hutan rakyat. Pengumpulan data dilakukan dengan cara: (1) Observasi, (2) Wawancara atau komunikasi langsung dengan responden dan informan kunci dengan bantuan kuisioner, (3) Studi literature yaitu pengumpulan data dari jurnal, buku, hasil penelitian, karya ilmiah, hasil seminar. Data primer yang diambil meliputi identitas responden, luas kepemilikan lahan, jumlah tanaman, cara pengelolaan lahan, harga jual kayu, biaya pengusahaan hutan rakyat, suku bunga pinjaman, pendapatan petani dari berbagai sumber. Sedangkan data sekunder yaitu monografi desa, luas hutan rakyat dan data lain yang mendukung kajian

\section{Metode Analisis Data}

Analisis kontribusi hutan rakyat terhadap pendapatan rumah tangga petani dilakukan dengan menghitung pendapatan yang diperoleh dari usaha hutan rakyat, usaha pertanian non hutan rakyat dan non usaha pertanian. Analisis data dilakukan secara deskriptif.

Analisis kontribusi hutan rakyat terhadap ketahanan pangan dilakukan dengan menghitung total ketersediaan energi dari seluruh hasil produksi tanaman baik pangan maupun non pangan dengan satuan kap/kal/hr.
Ketersediaan energi dari produksi tanaman non pangan dinilai dengan menghitung pendapatan hasil penjualan dan disetarakan dengan kandungan energi pangan pokok beras. Perhitungan kandungan energi dari setiap komoditi dilakukan dengan menggunakan Daftar Komposisi Bahan Makanan (DKBM) dengan cara sebagai berikut (Hardinsyah dan Martianto 1989):

$$
G i j=\frac{B P j}{100} \times \frac{B D D j}{100} \times K G i j
$$

Keterangan:

Gij = kandungan zat gizi tertentu (i) dari pangan $-\mathrm{j}$ per 100 gram yang dapat dimakan

$\mathrm{BPj}=$ berat pangan $-\mathrm{j}(\mathrm{gr})$

$\mathrm{BDDj}=$ bagian yang dapat dimakan dari 100 gram pangan - $\mathrm{j}$

KGij = zat gizi $-\mathrm{i}$ yang dikandung dari pangan $-\mathrm{j}$

Tingkat kecukupan energi dari hutan rakyat dihitung dengan membandingkan konsumsi energi dengan angka kecukupan gizi (AKG) yang dianjurkan per hari. Berdasarkan Peraturan Menteri Kesehatan No. 75 tahun 2013 menetapkan rata-rata kecukupan energi penduduk Indonesia adalah sebesar $2150 \mathrm{kkal} /$ orang/hari.

Untuk mengukur derajat ketahanan pangan tingkat rumah tangga, digunakan pangsa pangan, yaitu klasifikasi silang dua indikator ketahanan pangan, yaitu pangsa pengeluaran pangan dan kecukupan konsumsi energi (Kkal) (Jonsson dan Toole 1991 diacu dalam Maxwell and Frankenberger 1992) seperti yang ditunjukkan pada Tabel 1. Batasan 80 persen dari konsumsi energi (per unit ekivalen dewasa) dikombinasikan dengan pangsa pengeluaran pangan $>60$ persen dari total pengeluaran rumah tangga. Berikut adalah empat kategori rumah tangga menurut tingkat ketahanan pangan :

a. Tahan pangan (pangsa pangan $<60 \%$, kecukupan energi > 80\%),

b. Rentan pangan (pangsa pangan $\geq 60 \%$, kecukupan energi > 80\%),

c. Kurang pangan (pangsa pangan $<60 \%$, kecukupan energi $\leq 80 \%$ ), dan

d. Rawan pangan (pangsa pangan $\geq 60 \%$, kecukupan energi $<80 \%)$.

Tabel 1 Ketahanan pangan: kecukupan energi dan pangsa pengeluaran pangan

\begin{tabular}{lcc}
\hline Kecukupan konsumsi energi per & \multicolumn{2}{c}{ Pangsa pengeluaran pangan } \\
\cline { 2 - 3 } unit ekuivalen dewasa & $\begin{array}{c}\text { Rendah } \\
(\leq 60 \% \text { pengeluaran total })\end{array}$ & $\begin{array}{c}\text { Tinggi } \\
(>60 \% \text { pengeluaran total })\end{array}$ \\
\hline $\begin{array}{l}\text { Cukup } \\
\begin{array}{l}\text { Kurang syarat kecukupan energi) } \\
(\leq 80 \% \text { syarat kecukupan energi) }\end{array}\end{array}$ & 1. Tahan Pangan & 2. Rentan Pangan \\
\hline
\end{tabular}

Sumber: Jonsson dan Toole 1991 diacu dalam Maxwell dan Frankenberger 1992 


\section{HASIL DAN PEMBAHASAN}

\section{Kontribusi Pendapatan Hutan Rakyat terhadap Total Pendapatan Petani}

Sumber pendapatan petani hutan rakyat di lokasi penelitian berasal dari tiga sumber, yaitu hutan rakyat, non hutan rakyat, dan lain-lain. Pendapatan hutan rakyat berasal dari penjualan kayu, buah, tanaman obat dan tanaman palawija. Pendapatan non hutan rakyat diperoleh dari hasil kegiatan pertanian di sawah. Sedangkan pendapatan non usaha tani berasal pegawai, buruh tani, beternak, berdagang, dan wiraswasta lainnya.

Hal ini menunjukkan bahwa pendapatan dari hutan rakyat menjadi sumber pendapatan utama petani. Menurut Hardjanto (2003) intensitas pengelolaan dan perhatian terhadap usaha hutan rakyat berdasarkan pola tanaman hutan rakyat dengan sistem agroforestry lebih tinggi dibandingkan dengan hutan rakyat campuran. Pendapatan dari pertanian merupakan pendapatan utama dari sebagian besar responden. Pendapatan dari pengusahaan hutan rakyat diperoleh dari penjualan

Tabel 2 Kontribusi berbagai sumber pendapatan terhadap pendapatan total rumah tangga petani

\begin{tabular}{|c|c|c|c|c|c|}
\hline & Sumber pendapatan & $\begin{array}{c}\text { Luas rata-rata Kepemilikan } \\
\text { lahan (ha) }\end{array}$ & $\begin{array}{c}\text { Pendapatan } \\
\text { (Rp/tahun) }\end{array}$ & $\begin{array}{l}\text { Pendapatan Rata-rata } \\
\text { (Rp/tahun) }\end{array}$ & Persen $(\%)$ \\
\hline \multicolumn{6}{|c|}{ Desa Leuwibatu } \\
\hline a. & HR Kayu & & 134550047.85 & 6115911.27 & 12.36 \\
\hline b. & HR Tanaman Pangan & & 336470000.00 & 16978181.82 & 28.58 \\
\hline c. & Total HR & 0.84 & 471020047,85 & 23094093.08 & 40.94 \\
\hline d. & Pertanian & 0.36 & 315800000.00 & 14354545.45 & 34.90 \\
\hline e. & Pekarangan & 0.14 & 13120000.00 & 624761.90 & 3.69 \\
\hline f. & Lain-Lain & & 345525000.00 & 15705681.82 & 21,01 \\
\hline \multicolumn{6}{|c|}{$\underline{\text { Desa Cidokom }}$} \\
\hline a. & HR Kayu & & 104392424.42 & 4538801.06 & 11.16 \\
\hline b. & HR Tanaman Pangan & & 354200000.00 & 15602532.00 & 29.97 \\
\hline c. & Total HR & 0.67 & 458592424,42 & 19938801.06 & 41.13 \\
\hline d. & Pertanian & 0.47 & 520100000.00 & 27373684.21 & 40.74 \\
\hline e. & Pekarangan & 0.03 & 16500000.00 & 4125000.00 & 5.97 \\
\hline f. & Lain-Lain & & 266780000.00 & 18002184.87 & 12.52 \\
\hline \multicolumn{6}{|c|}{ Desa Mekarjaya } \\
\hline a. & HR Kayu & & 81398484.85 & 3876118.33 & 8.37 \\
\hline b. & HR Tanaman Pangan & & 315420000.00 & 15020320.00 & 32.10 \\
\hline c. & Total HR & 3.60 & 396818484,85 & 18896118.33 & 40.46 \\
\hline d. & Pertanian & 1.98 & 219700000.00 & 12923529.41 & 24.71 \\
\hline e. & Pekarangan & 0.53 & 38400000.00 & 6420000.00 & 7.40 \\
\hline f. & Lain-Lain & & 435826000.00 & 32754000.00 & 48,78 \\
\hline
\end{tabular}

Tabel 3 Pengeluaran rumah tangga petani

\begin{tabular}{|c|c|c|c|c|c|c|c|c|}
\hline \multirow[b]{2}{*}{ Desa } & \multicolumn{8}{|c|}{ Rata-rata Pengeluaran (Rp/tahun) } \\
\hline & Pangan & Rokok & Pendidikan & Tekomunikasi & Lain-lain ${ }^{a}$ & $\begin{array}{c}\text { Total Non } \\
\text { Pangan }\end{array}$ & $\begin{array}{c}\% \\
\text { Panga } \\
n\end{array}$ & $\begin{array}{c}\% \\
\text { Non } \\
\text { Panga } \\
\text { n }\end{array}$ \\
\hline Leuwibatu & 5841363.64 & 3558068.18 & 2490000.00 & 646363.64 & 2999545.45 & 9693977.27 & 63.74 & 36.26 \\
\hline Cidokom & 8914576.09 & 2201097.83 & 813043.48 & 1597391.30 & 10780304.35 & 9898876.79 & 65.17 & 34.83 \\
\hline Mekarjaya & 14895238.10 & 3416154.76 & 3077619.05 & 642857.14 & 3286190.48 & 10422821.43 & 63.24 & 36.76 \\
\hline Rata-rata & 13217059.27 & 3058440.26 & 2126887.51 & 962204.03 & 5688680.09 & 10005225.17 & 64.05 & 35,95 \\
\hline
\end{tabular}


produk kayu rakyat dan produksi tanaman pangan. Tabel 2 menunjukkan bahwa rata-rata pendapatan petani hutan rakyat di ketiga desa sama yaitu sebesar $\pm 40 \%$ dari total pendapatan.

Pendapatan yang berasal dari kayu rakyat pada ketiga desa tersebut hanya sebesar $10.63 \%$. Hal ini menunjukkan bahwa petani tidak menebang kayu rakyat dalam skala besar, melainkan melakukan tebang butuh. Pilihan menebang kayu merupakan pilihan terakhir jika sumber pendapatan dari pertanian atau pekarangan atau usaha lain belum mencukupi.

\section{Pengeluaran Petani Hutan Rakyat}

Pengeluaran petani terdiri dari pengeluaran pangan dan non pangan. Pengeluaran pangan berupa beras, ubiubian, minyak dan lemak, pangan hewani, pangan nabati, kacang-kacangan, gula, sayur-sayuran, bumbubumbuan, buah-buahan dan minuman. Sedangkan pengeluaran non pangan terdiri dari pendidikan, rokok, komunikasi, perabotan rumah, perbaikan rumah, pakaian dan lain-lain. Pengeluaran rumah tangga petani terbesar terdapat pada pengeluaran pangan rata-rata sebesar $64.5 \%$ (Tabel 3). Pengeluaran pangan yang cukup tinggi ini menunjukkan bahwa kesejahteraan masyarakat masih rendah. Hukum Engel menyatakan bahwa pengeluaran pangan yang lebih besar (lebih dari 50\%) dari

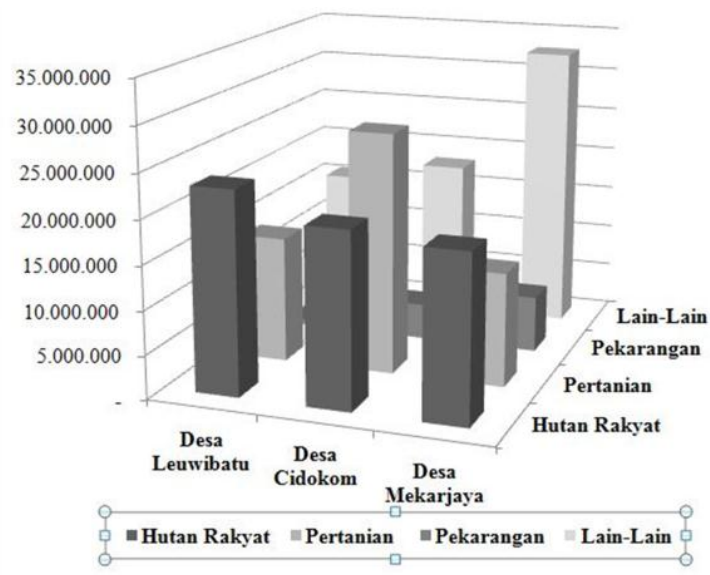

Gambar 1 Grafik kontribusi hutan rakyat, pertanian dan usaha lain terhadap pendapatan petani

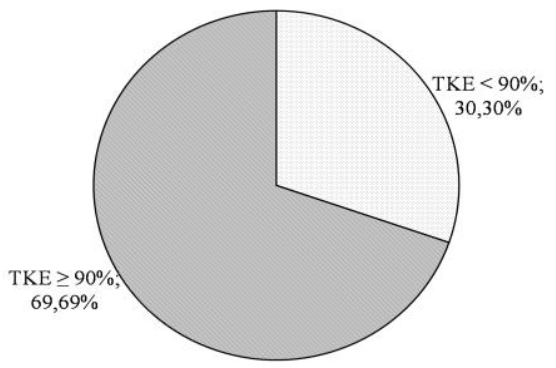

Gambar 2 Sebaran rumah tangga berdasarkan ketersediaan energi pengeluaran lainnya menandakan bahwa masyarakat tersebut belum sejahtera (Widyaningsih dan Muflikhatul 2015).

\section{Pengaruh pendapatan dari Hutan Rakyat terhadap Total Pendapatan Petani}

Untuk mengetahui pengaruh hutan rakyat terhadap total pendapatan rumah tangga petani hutan rakyat, digunakan metoda regresi linear berganda. Sebagai variabel bergantung (independent variable) adalah total pendapatan, sedangkan variabel bebas (dependent variable) pertama adalah pendapatan dari hutan rakyat, variabel bebas kedua adalah pendapatan dari pertanian, dan variabel bebas ketiga adalah pendapatan dari usaha lain. Nilai variabel bebas maupun variabel bergantung diukur dalam satuan juta rupiah (Rp 000 000,-).

Persamaan yang di dapat adalah sebagai berikut:

$\mathrm{Y}=8,019+2,035 \mathrm{X} 1+0,961 \mathrm{X} 2+0,928 \mathrm{X} 3$

Atau

Pendapatan $=8,019+2,035$ (Hutan Rakyat $)+0,961$

(Pertanian) $+0,928$ (Usaha Lain)

Dengan melihat konstanta dan nilai t hitung dapat diketahui bahwa Hutan Rakyat memberikan kontribusi pendapatan masyarakat yang paling tinggi. Perhitungan secara keseluruhan pendapatan Desa Leuwibatu, Desa Cidokom dan Desa Mekarjaya dari sektor hutan rakyat lebih tinggi dari pendapatan dari sektor pertanian (Gambar 1). Gambaran kontribusi hutan rakyat, pertanian dan usaha lain terhadap pendapatan pada masing-masing desa adalah sebagai berikut:

\section{Daya dukung energi}

Besarnya daya dukung energi tanaman dari lahan hutan rakyat untuk melihat kontribusi energi dari tanaman pangan yang dihasilkan dari hutan rakyat terhadap kebutuhan energi dari setiap anggota rumah tangga petani.

Rata-rata daya dukung energi yang tertinggi adalah

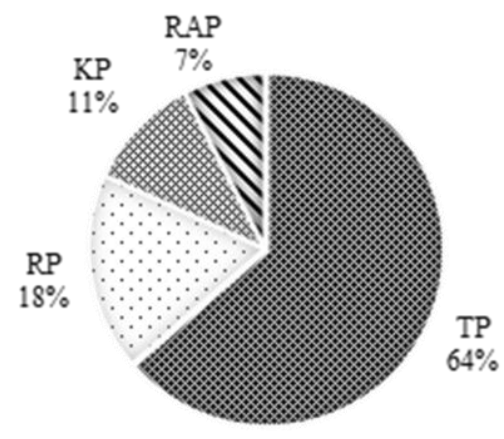

Gambar 3 Sebaran derajat ketahanan pangan rumah tangga 
dari Singkong $(4205,79 \mathrm{kkal} / \mathrm{kapita} / \mathrm{hr})$, kemudian jagung $(2.331,31 \mathrm{kal} / \mathrm{kapita} / \mathrm{hr})$, dan pisang $(1455,09$ $\mathrm{kal} / \mathrm{kap} / \mathrm{hr}$ ). Sementara yang terendah adalah Jambu air (Ipomoea batatas), Jeruk limau (Citrus amblycarpa), Rebung (Bambusa sp), Timun (Trichosanthes cucumeroidesmaxim), Timun suri, dan Tomat (Solanum lycopersicum) dengan rata-rata dibawah 10.00 $\mathrm{kal} / \mathrm{kap} / \mathrm{hr}$ (Tabel 4)

Daya dukung gizi atau ketersediaan energi dari hasil produksi non pangan setara beras diperoleh dengan mengalikan seluruh hasil produksi non pangan dengan harga jual setiap komoditas, kemudian dibagi dengan harga beras. Penyetaraan dengan harga beras ini berdasarkan atas jenis pangan pokok pada daerah

Tabel 4 Rata-rata daya dukung energi tanaman pangan dari hutan rakyat

\begin{tabular}{|c|c|c|c|c|}
\hline \multirow{2}{*}{ No } & \multirow{2}{*}{ Tanaman Pangan } & \multicolumn{3}{|c|}{ Daya Dukung Energi (Kal/kapita/hr) } \\
\hline & & Jumlah & Rata-rata & Max \\
\hline 1 & Alpukat (Persea americana) & 3108.90 & 50.14 & 768,49 \\
\hline 2 & Buah Menteng(Baccaurea javanica) & 854.79 & 14.01 & 178,08 \\
\hline 3 & Cabai merah (Capsicum annuum sp) & $1.488,42$ & 24.40 & 465,00 \\
\hline 4 & Cempedak (Arthocarpus champeden) & 953,42 & 15.38 & 794,52 \\
\hline 5 & Cengkeh (Syzygium aromaticum) & $4.931,51$ & 79.54 & $2.958,90$ \\
\hline 6 & Duku (Lansium domesticum) & $55.112,05$ & 888.90 & $8.630,14$ \\
\hline 7 & Durian (Durio zibetinus) & $38.848,99$ & 626.60 & $11.013,70$ \\
\hline 8 & Jagung (Zea mays $L)$ & $97.915,07$ & 2331.31 & $29.671,23$ \\
\hline 9 & Jambu air (Ipomoea batatas) & 315,07 & 5.34 & 252,05 \\
\hline 10 & Jambu Monyet Daun(Anacardium occidentale) & $15.510,00$ & 250.16 & $7.000,00$ \\
\hline 11 & Jengkol (Archidendron pauciflorum) & $4.208,22$ & 67.87 & 657,53 \\
\hline 12 & Jeruk bali (Citrus maxima) & 986,30 & 16.72 & 591,78 \\
\hline 13 & Jeruk limau (Citrus amblycarpa) & 283,84 & 4.89 & 152,05 \\
\hline 14 & Kacang Panjang (Vigna sinensis) & 687,12 & 13.21 & 241,10 \\
\hline 15 & Kacang Tanah (Arachis hypogaea) & $33.082,19$ & 636.20 & $14.383,56$ \\
\hline 16 & Kecapi (Sandoricum koetjape) & 922,60 & 14.88 & 669,86 \\
\hline 17 & Kelapa (Cocos nucifera) & $71.327,89$ & 1.150 .45 & $24.589,04$ \\
\hline 18 & Kencur (Kaempferia galanga) & $1.072,60$ & 17.88 & 258,90 \\
\hline 19 & Ketela Rambat (Ipomoea batatas) & $1.967,67$ & 31.74 & 780,82 \\
\hline 20 & kokosan (Lansium aqueum) & $2.709,59$ & 43.70 & $1.178,08$ \\
\hline 21 & Kopi (Coffea robusta) & $2.410,96$ & 38.89 & 964,38 \\
\hline 22 & Kunyit (Curcuma longa L) & $3.365,75$ & 54.29 & 863,01 \\
\hline 23 & Kuweni (Mangifera odorata) & $7.560,34$ & 121.94 & $1.109,59$ \\
\hline 24 & lengkuas (Alpinia galanga $L$ ) & $14.461,37$ & 233.25 & $2.121,64$ \\
\hline 25 & Lobi-lobi (Flacourtia inermis) & 283,56 & 4.57 & 86,30 \\
\hline 26 & Mangga (Mangifera indica) & $9.767,12$ & 157.53 & $1.643,84$ \\
\hline 27 & Manggis (Garcinia mangostana) & $4.720,68$ & 76.14 & $1.121,92$ \\
\hline 28 & Melinjo (Gnetum gnemon) & $17.945,21$ & 289.44 & $5.753,42$ \\
\hline 29 & Nangka (Artocarpus integra) & $17.047,12$ & 274.95 & $1.742,47$ \\
\hline 30 & Pepaya (Carica papaya) & $1.272,88$ & 20.87 & 302,47 \\
\hline 31 & Petai (Parkia speciosa) & $11.398,90$ & 183.85 & $1.945,21$ \\
\hline 32 & Pisang Ambon (Musa sp) & 719,18 & 11.60 & 719,18 \\
\hline 33 & Pisang (Musa sp) & $90.215,75$ & 1455.09 & $11.342,47$ \\
\hline 34 & Rambutan (Niphelium lappaceum) & $26.084,52$ & 420.72 & $2.835,62$ \\
\hline 35 & Rebung (Bambusa sp) & 343,97 & 5.55 & 73,97 \\
\hline 36 & Salam (Syzygium polyanthum) & $24.509,59$ & 395.32 & $14.794,52$ \\
\hline 37 & Sawo (Manilkara zapota) & 579,73 & 10.54 & 252,05 \\
\hline 38 & Sereh (Cymbopogon Nardus L) & 34619,18 & 558.37 & 4931,50 \\
\hline 39 & Singkong (Manihot esculenta) & $214.495,29$ & 4205.79 & $40.000,00$ \\
\hline 40 & Sukun (Artocarpus altilis) & $7.103,84$ & 116.46 & $2.650,68$ \\
\hline 41 & Talas (Colocasia esculenta) & $1.409,59$ & 22.74 & 268,49 \\
\hline 42 & Timun (Trichosanthes cucumeroidesmaxim) & 151,23 & 2.44 & 98,63 \\
\hline 43 & Timun Suri (Cucumis mel L) & 550,68 & 8.88 & 164,38 \\
\hline 44 & Tomat (Solanum lycopersicum) & 291,10 & 4.70 & 136,99 \\
\hline 45 & Bambu (Bambusa sp) & $4.671,78$ & 122.94 & $1.315,07$ \\
\hline 46 & Kayu (setara beras & $282.146,14$ & $4.625,35$ & $24.657,53$ \\
\hline \multicolumn{2}{|c|}{ Rata-rata } & $24.244,92$ & 393,70 & $4.937,61$ \\
\hline
\end{tabular}


penelitian adalah beras. Komoditas produksi non pangan antara lain: tanaman Cengkeh (Syzygium aromaticum), Kopi (Coffea robusta), Salam (Syzygium polyanthum), dan Bambu (Bambusa sp) (Tabel 4).

Tanaman singkong, jagung, dan pisang mampu memenuhi kebutuhan energi harian dari petani hutan rakyat pengelolanya, yakni berdasarkan Peraturan Menteri Kesehatan No. 75 tahun 2013, dasar rata-rata kecukupan energi penduduk Indonesia adalah sebesar 2150 kkal per orang per hari. Sedangkan ketersediaan energi pangan rumah tangga petani yang berasal dari hutan rakyat jika dibandingkan dengan kebutuhan standar sebesar $2150 \mathrm{kkal}$, maka ketersediaan energi yang berasal dari lahan hutan rakyat dapat dibedakan dalam kategori kurang (TKE $<90 \%$ ), dan cukup (TKE $\geq$ $90 \%$ ). Sebaran rumah tangga petani berdasarkan daya dukung gizi atau ketersediaan energi disajikan dalam Gambar 2.

Sebaran rumahtangga yang mempunyai persentase TKE $\geq 90 \%$ adalah sebesar $69,69 \%$, dan $30,30 \%$ rumahtangga memiliki TKE $<90 \%$. Hal ini menunjukkan bahwa produksi tanaman pangan yang dihasilkan dari hutan rakyat pada lokasi penelitian memiliki angka TKE sedikit lebih tinggi dari angka TKE yang ada di lokasi penelitian Indah (2009) yaitu di HKm di Kabupaten Lampung Barat yang memiliki angka TKE $\geq 90 \%$ sebesar $67,8 \%$ dari rumah tangga contoh.

\section{Derajat ketahanan pangan rumah tangga dari hutan rakyat}

Derajat ketahanan pangan tingkat rumah tangga petani yang digunakan adalah pangsa pangan, yaitu klasifikasi silang dua indikator ketahanan pangan, yaitu pangsa pengeluaran pangan dan kecukupan konsumsi energi (Kkal) (Jonsson dan Toole 1991 dalam Maxwell and Frankenberger 1992). Batasan 80 persen dari konsumsi energi (per unit ekivalen dewasa) dikombinasikan dengan pangsa pengeluaran pangan $>60$ persen dari total pengeluaran rumah tangga. Kategori ini dibagi menjadi 4 (empat), yaitu: 1) Rumah tangga Tahan pangan (TP), 2) Rumah tangga rentan pangan (RP), 3) Rumah tangga kurang pangan (KP), dan 4) rumah tangga rawan pangan (RAP). Jumlah rumah tangga yang tahan pangan sebesar 64\%, rentan pangan sebesar $18 \%$, dan rawan pangan sebesar 7\%, (Gambar 3).

Perbedaan rumah tangga yang tahan pangan dan rentan pangan adalah terletak pada pangsa pangan atau total pengeluaran pangan rumah tangga, yaitu rumah tangga tahan pangan memiliki pangsa pangan $<60 \%$, kecukupan energi >80\%), sedangkan rumah tangga rentan pangan (pangsa pangan $\geq 60 \%$, kecukupan energi $>80 \%$ ). Hal ini bisa mengakibatkan ketidakstabilan kecukupan energi rumah tangga, ketika kecukupan energi berkurang sampai dengan $<80 \%$, sehingga terjadi kondisi rawan pangan.

\section{SIMPULAN}

Hutan rakyat berkontribusi terhadap ketahanan rumah tangga. Terdapat 46 jenis tanaman pangan yang ditanam pada hutan rakyat di Kecamatan Rumpin dengan kontribusi terhadap rata- rata ketahanan pangan rumah tangga petani per hari sebesar $393.70 \mathrm{kal} / \mathrm{kap} / \mathrm{hr}$. Kontribusi pendapatan pada usaha pengembangan hutan rakyat merupakan kontribusi terbesar dari total pendapatan yang diterima petani, yaitu sebesar $40,84 \%$. Sebaran rumah tangga berdasarkan ketersediaan energi yang berasal dari lahan hutan rakyat persentase TKE $\geq$ $90 \%$ sebanyak 69,69\% dan sisanya memiliki TKE < $90 \%$. Derajat ketahanan pangan tingkat rumah tangga petani hutan rakyat berdasarkan pangsa pangan, diperoleh jumlah rumah tangga yang tahan pangan sebesar 64\%, rumah tangga rentan pangan sebesar $18 \%$, dan rumah tangga yang rawan pangan sebesar $7 \%$.

\section{UCAPAN TERIMA KASIH}

Ucapan terima kasih dan penghargaan penulis sampaikan kepada Kementerian Lingkungan Hidup dan Kehutanan yang telah membiayai penelitian. Ucapan terima kasih penulis juga sampaikan kepada Komisi Pembimbing Fakultas Kehutanan IPB (Prof. Hardjanto dan Dr. Yulius Hero), rekan-rekan Sekretariat Badan P2SDM.

\section{DAFTAR PUSTAKA}

Aju PC. 2014. The Role of forestry in agriculture and food Security. American Journal of Research Communication. 2(6) : 109-121.

Bangsawan I dan Dwiprabowo H. 2012. Hutan sebagai penghasil pangan untuk ketahanan pangan masyarakat: studi kasus di Kabupaten Sukabumi . Jurnal Analis Kebijakan.[Balitbanghut] Badan Penelitian dan Pengembangan Kehutanan Kementerian Kehutanan. 9(4): 185-197

[BPS] Badan Pusat Statistik. 2016. Laporan bulanan data sosial ekonomi. Jakarta[ID]. Edisi 60: 47-49

Chung KL, Haddad L, Ramakrishna J, Riely F. 1997. Identifying the foodinsecure, the apllication on mixed-method approaches in India. Washington DC (US): International Food Policy Reserch Institute.

Darusman D, Hardjanto. 2006. Tinjauan Ekonomi Hutan Rakyat; 2006; Bogor, Indonesia.Prosiding Seminar Hasil Hutan. Bogor (ID): Fakultas Kehutanan IPB. hlm 4-13.

Darusman D, Puspitojati T, Mile YM, Fauziah E. 2014. Hutan Rakyat Sumbangsih Masyarakat Pedesaan untuk Hutan Rakyat. Bahruni, editor. Yogyakarta [ID]: Penerbit Kanisisus. Cetakan 1.

De Foresta H, A Kusworo, G Michon, WA Djatmiko. 2000. Ketika Kebun Berupa Hutan - Agroforest 
Khas Indonesia - Sebuah Sumbangan Masyarakat. ICRAF, Bogor [ID]. Hal : 248-250.

[Dephut] Departemen Kehutanan. 2009. Pangan dari hutan (Kontribusi Sektor Kehutanan dalam Mendukung Ketahanan Pangan Nasional). Makalah Seminar Nasional "Memantapkan Ketahan Pagan Nasional Mengantisipasi Krisis Global" dalam rangka Hari Pangan Sedunia 12 Oktober 2009). Jakarta [ID]. [Distanhut] Dinas Pertanian dan Kehutanan Kabupaten Bogor. 2011. MonografiPertanian dan Kehutanan Kabupaten Bogor Tahun 2011. Bogor: Dinas Pertanian dan Kehutanan Kabupaten Bogor.

Dwiprabowo H, Effendi R, Hakim I, Bangsawan I. 2011. Kontribusi kawasan hutan dalam menunjang ketahanan pangan: studi kasus di Provinsi Jawa Barat. Jurnal Analis Kebijakan. [Balitbanghut Badan Penelitian dan Pengembangan Kehutanan Kementerian Kehutanan]. 8(1) : 47-61.

[FAO] Food and Agriculture Organization. 2006. Food Security, Policy Brief. June 2006 Issue 2[Internet]. Tersedia pada http://www.fao.org/forestry/131 28.pdf. [diunduh 28 Maret 2015].

Hardinsyah, Martianto D. 1989. Menaksir Kecukupan Energi dan Protein serta Penilaian Mutu Gizi Konsumsi Pangan. Jakarta [ID]: Wirasari.

Hardjanto. 2000. Beberapa ciri pengusahaan hutan rakyat di Jawa. Di dalam: Suharjito D, editor. Hutan rakyat di Jawa perannya dalam perekonomian desa. Bogor (ID): Program Penelitian dan Pengembangan Masyarakat (P3KM). hlm 7-11.

Hardjanto. 2003. Keragaan dan Pengembangan Usaha Kayu Rakyat di Pulau Jawa[Disertasi].Bogor [ID]: Institut Pertanian Bogor.

Jonsson U, Toole D. 1991. Conceptual Analysis of Resources and Resource Control in Relation to Malnutrition, Disease and Mortality, mimeo, UNICEF. New York.

[Kemenhut]. Kementerian Kehutanan RI. 2013. Statistik Kementerian Kehutanan Tahun 2013. Jakarta[ID]. Ditjen Planologi Kehutanan.

Maxwell S, Frankenberger TR. 1992. Household Food Security: Conscepts, Indicators, Measurements. A Technical Review. Italy-Newyork.UNICEF-IFAD.

Mbow C, Noordwijk V M, Luedeling E, Neufeldt H, Minang AP, Kowero G. 2014. Agroforestri solutions to address food security and climate challenges in Africa. Current Opinion in Environmental Sustainability. 6: 61-67. doi:10.1016/j.cosust.2013.10.014.
Mudhofir TRM. 2015. Karakteristik, Potensi dan Kontribusi Hutan Rakyat di Kabupaten Bogor [skripsi]. Bogor (ID): Institut Pertanian Bogor.

Pemkab Bogor. 2015. Pengentasan Kemiskinan Jadi Perhatian Serius Pemkab Bogor [Internet]. [diunduh 20 April 2016]. Tersedia pada:http://www.bogorkab.go.id/2014/03/04/penge ntasan-kemiskinan-jadi-perhatian-serius-pemkabbogor/.

Pimentel D, McNair M, Buck L, Pimentel M, Kamil J. 1997. The Value of forest to world food security. Human Ecology. 25(1): 91-120. doi. 10.1023/A: 1021987920278.

Rachman RA. 2009. Sistem pengelolaan dan kontribusi kebun campuran terhadap pendapatan rumah tangga di Desa Sukadamai, Kecamatan Cicantayan, Kabupaten Sukabumi, Jawa Barat [skripsi]. Bogor (ID): Institut Pertanian Bogor.

Suhardi, Sambas S, Sri AS, Dwidjono HD, Minarningsih, Widodo A. 1999. Hutan dan Kebun Sebagai Sumber Pangan Nasional. ISBN 979-606012-4. Kerjasama antara: Departemen Kehutanan dan Perkebunan, Departemen Pertanian, Kantor Menneg Pangan dan Hortikultura dan Universitas Gadjah Mada. Departemen Kehutanan dan Perkebunan RI, Jakarta[ID].

Suhardjo. 1996. Pengertian dan Kerangka Pikir Ketahanan Pangan Rumah Tangga. Makalah disampaikan pada Lokakarya Ketahanan Pangan Rumah Tangga. Yogyakarta, 26-30 Mei.

Syarief H. 1992. Metode Ststistika untuk Pangan dan Gizi Masyarakat. Depertemen Pendidikan dan Kebudayaan, Direktorat Jenderal Pendidikan Tinggi, Pusat antar Universitas Pangan dan Gizi. Institut Pertanian Bogor. Bogor [ID].

Umar Husein. 2003.Metode Riset Perilaku Konsumen Jasa, Gramedia Pustaka Indonesia, Jakarta [ID].

[WHO] World Health Organization. 2013. Food Security On Trade, Foreign Policy Diplomacy and Health [Internet].[diacu 28 Maret 2015]. Tersedia dari: http://www.who.int/trade/glossary/story 028/en/.

Widiarti A. 2004. Gerhan : Hutan rakyat lebih menjanjikan penyediaan kayu, pangan dan pelestarian lingkungan. Prosiding Ekspose Penerapan Hasil Litbang Hutan dan Konservasi Alam. Puslitbang Hutan dan Konservasi Alam [Balitbanghut]. Bogor. Hal : 186-193. 